\title{
The uses of wolfberry (Lycium barbarum L.) as a fruit in an international breadth of view
}

\author{
Sóspataki, R., Józsa, M. \& Simon, G. \\ ${ }^{1}$ Corvinus University of Budapest Faculty of Horticulture, Department of Pomology
}

\begin{abstract}
Summary: Lycium barbarum is known exclusively as an ornamental plant in Hungary, and is planted so, as popular belief deem it a toxic plant. The plant's fruit receives great respect in countries abroad, thus, due to its favourable content values the Lycium has achieved the title of 'biological gold mine'. The last couple of years has seen the import of Lycium shrubs and its corresponding products, dried goods or in the form of various processed products which have been marketed and sold at extreme prices (under name of Goji, Wolfberry, Lifeberry). Our goal was to examine the similarities of the content values of wolfberry found in Hungary and those cultivated abroad. Along with Miklós Józsa the domestic Lycium population was surveyed based on foreign examples, between the years 2009 and 2011. Those defined sweet and largefruited were selected for further investigations to be set into a clone repository. This clone repository- which contains 67 different clones from a number of regions of Hungary - was established in the nursery of Dr. Miklós Józsa, located in the city of Szombathely. The phenological and morphological characteristics and the fruit ripening and quality indicators of plants in the clone repository were investigated. Six 'best' clones - selected based on flavour, disease-resistance and vegetative characteristics (plant size, fruit set, yield and fruit size) were analysed based on their content values. The control plant was a cultivar imported by a delivery service, found also in growing. In addition to the results of the selection, the results of the content values of the six selected 'best' clones (total soluble sugar content, glucose-fructose ratio, carotene content, FRAP value) is documented in this paper. Further, based on the resulting information the possibilities of the fruit's utilization are suggested. Significant differences were measured in the vegetative characteristics of the clones (plant size, fruit set, yield and fruit size) and of those of its inner content values. The resulting properties are considerable in regards of the plant's introduction into cultivation and also utilization. Based on growing characteristics, more favourable clones were selected than the foreign varieties already in growing. Those clones selected by us have had similar or better content values than foreign breeds. The investigation of these content values is still in progress.
\end{abstract}

Keywords: Lycium barbarum, Goji berry, Wolfberry, Antioxidant, HPLC, FRAP

\section{Introduction}

Wolfberry (Lycium barbarum) is related to the shrub family of solanaceous (Solanaceae). The vegetative organs of the plant (belonging to this family) are rich in alkaloid and many of them are ornamental plants (Vancsura, 1992). The Lycium genus is made up of approximately 80-90 species (Krüssmann, 1977). There are 15 native species in Europe, most can be found in the Mediterranean region (Vancsura, 1992). 7 Lycium species, 3 varieties and 35 various cultivated plant type can be found in China. The most respected type is the Lycium barbarum thanks to its curative influence (Young et. al., 2006).

It is spread widely: South and Central Europe, North Africa, West Asia, North America. It is an adventive plant to most regions, originating most likely from Central China. The occurrence in Hungary is frequent, however the plant is absent in some regions (ie: northern part of the Great Plain) (Bartha, 1999).

Wolfberries (syn. name Goji) are able to grow in all soil types and exposure, and tolerate the heavily saline soil as well (Schmidt, 1996).

Lycium barbarum most probably got its name from the province of Lycia, located in Asia Minor. Chinese call the plant itself 'gouqi', and the fruit 'gouqizi', 'zi' meaning small fruit. This is where the name 'Goji' has evolved from (Young et. al., 2006).

Wolfberries are long-living and fast growing 2-3 m high deciduous plants (Schmidt \& Tóth, 2006). The plant can be characterized by shoots and branches, with significant number of thin branches emerging from the rootstock (Bartha, 1999). Young shoots are upright, and will take curved shapes later. (Vancsura,1992). Wolfberry leaves can take many forms, may have lanceolate spear point or elliptic, mid-widening shape (Bartha, 1997). The flowers grow segregated in the leaf axils of the long shoot, and in bundles of two to five of the short shoot (Bartha, 1999). The flowering often starts in May and may continue until September or even October, which makes the wolfberry a valued apiculture plant (Halmágyi, 1991). Fruits are in clusters of one to four, round to eggshaped, green colour at first (Bartha, 1997). Ripe berries turn bright red, are 1.5-2 cm long, and contain small sized seeds numbering 10-15 (Vancsura, 1992). The seeds are 2.2-2.8 $\mathrm{mm}$ long, wide oval shaped, are laterally compressed from its sides, have fine degree of spherical surface and are orangered coloured (Bartha, 1997).

There is no information on consumption of crops in Hungary. This can be justified as authoritative publications 
consider the fruits toxic, and thus do not recommend consumption under any circumstances (Pap, 2010).

Wolfberry can be easily vegetative propagated by green, semi-hardwood and hardwood cuttings. Cuttings are able to get good root even among inappropriate conditions. Generative propagation is also known by seeding from September through October (Schmidt, 1996).

Lycium genus is infected mainly by the powdery mildew (Arthrocladiella mougeotii - previously Erysihpe mougeotii), which is the only known species of the Arthrocladiella genus. Infected parts of the plant are slightly deformed, in case of serious infections the plant ornamental values may reduce (www.cabi.org, 2011). Its most common disease is the lineate patterns of the leaves and the yellow mosaic disease, however infected shrubs did not initiate markable growth reduction or weakening (Salamon, 2002).

Chinese have been consuming the wolfberry for 5000 years. Wolfberry has been cultivated in northern China and Tibet for a long time, nowadays primarily in the regions of Ningxia, Hei Bei, Xin Jiang and Inner Mongolia.

The crops are marketed as dried fruit, but numerous other product types are also produced. Wolfberry fruits have several wide-ranging, positive effects. More than $15 \%$ of its weight is composed of proteins, wolfberry contains more than 21 essential minerals, 18 amino acids and a considerable amount of chromium. Its vitamin content (vitamins $\mathrm{B}_{1}, \mathrm{~B}_{3}, \mathrm{C}$ ) is excessively (Table 1.). It has a strong supporting effect for the immune system by its outstanding high antioxidant content (Young et. al., 2006), (Table 2.).

Zeaxanthin and its esters are major contributors to the carotenoids in L. barbarum (Li et. al., 1998), (Weller \& Breithaupt, 2003). The content of zeaxanthin esters in ripening goji fruits can reach as high as $>77.5 \%$ of total carotenoids (Li et. al., 1998), (Peng et. al., 1988), (Table 2.). Zeaxanthin and other carotenoids are also potent antioxidants, which contribute to the health effects of goji berry against oxidative stress-mediated diseases.

Table 1. Nutrient data for dried goji berries compared with dried apricots (Source: Paul M. Gross, 2006. Tables Ciqual (AFFSA))

\begin{tabular}{|l|c|c|}
\hline \multirow{2}{*}{\multicolumn{1}{|c|}{ Nutrients }} & $\begin{array}{c}\text { Dried Goji } \\
\text { berries }\end{array}$ & Dried Apricot \\
\cline { 2 - 3 } & \multicolumn{2}{|c|}{ Value: $\mathbf{1 0 0}$ g } \\
\hline Energy (kcal) & 370 & 226 \\
\hline Protein (g) & 11.7 & 2.5 \\
\hline Sugar (g) & 67.7 & 46.3 \\
\hline Total lipid (Fat) (g) & 8.2 & 0.28 \\
\hline Fiber (g) & 10 & 13 \\
\hline Vitamin C (mg) & 29 & 3.8 \\
\hline Calcium (mg) & 112 & 55 \\
\hline Potassium (mg) & 1132 & 1520 \\
\hline Beta-carotene (microgram) & 7400 & 2280 \\
\hline
\end{tabular}

Table 2. Contents of zeaxanthin dipalmitate and total carotenoid in Fructus Lycii from different species of the genus Lycium in China (Source: Yong et. al., 2005.)

\begin{tabular}{|c|l|c|c|c|}
\hline \multicolumn{1}{|c|}{ Species } & $\begin{array}{c}\text { Con- } \\
\text { tents of } \\
\text { zeax- } \\
\text { anthin } \\
\text { dipalmi- } \\
\text { tate }(\%)\end{array}$ & $\begin{array}{c}\text { Con- } \\
\text { tents } \\
\text { of total } \\
\text { caro- } \\
\text { tenoid } \\
(\%)\end{array}$ & $\begin{array}{c}\text { Contents of } \\
\text { zeaxanthin } \\
\text { dipalmitate in } \\
\text { total carotenoids } \\
(\%)\end{array}$ \\
\hline 1 & L. dasystemum Pojark & 0.146 & 0.269 & 54.28 \\
\hline 2 & L. barbarum L. & 0.214 & 0.386 & 55.44 \\
\hline 3 & L. chinense Mill & 0.219 & 0.444 & 49.32 \\
\hline 4 & L. truncatum Y.C. Wang & 0.2 & 0.383 & 52.22 \\
\hline 5 & $\begin{array}{l}\text { L. } \text { eylindricum } \text { Kuang et } \\
\text { A.M. Lu }\end{array}$ & 0.174 & 0.345 & 50.43 \\
\hline 6 & L. ruthenicum Murr & 0.031 & 0.084 & 36.9 \\
\hline 7 & $\begin{array}{l}\text { L. chinense Mill. var. } \\
\text { potaninii A.M. Lu }\end{array}$ & 0.149 & 0.306 & 48.69 \\
\hline 8 & $\begin{array}{l}\text { L. dasystemum } \text { Pojark var. } \\
\text { rubricaulium A.M. Lu }\end{array}$ & 0.262 & 0.473 & 55.39 \\
\hline 9 & $\begin{array}{l}\text { L. barbarum } \text { L. var. } \\
\text { auranticarpum } \text { K.F. Ching }\end{array}$ & 0.011 & 0.035 & 31.43 \\
\hline
\end{tabular}

Table 3. Oxygen radical absorbance capacity (ORAC) of berries and other fruits (adapted from USDA 2010)

\begin{tabular}{|l|c|}
\hline \multicolumn{1}{|c|}{ Fruit } & ORAC (lmol TE/100 g) \\
\hline Acai berry & 102.700 \\
\hline Black currant & 7.957 \\
\hline Black raspberry & 19.220 \\
\hline Blackberry & 5.905 \\
\hline Blueberry & 4.669 \\
\hline Cranberry & 9.090 \\
\hline Elderberry & 14.697 \\
\hline Goji & 3.290 \\
\hline Gooseberry & 1.700 \\
\hline Grape & 1.837 \\
\hline Pomegranate & 4.479 \\
\hline Red currant & 3.387 \\
\hline Red raspberry & 5.065 \\
\hline Strawberry & 4.302 \\
\hline Apple & 2.500 \\
\hline Banana & 800 \\
\hline Orange & 2.000 \\
\hline
\end{tabular}

\section{Material and methods}

Gathering of Lycium genotypes in Hungary started in the summer of 2009. It was found 91-94\% of Lycium population has no valuable crop (fruits). During gathering sweet, thornless, less susceptible or resistant to disease examples were given priority. Various flowering, ripening times and different berry shapes and sizes were found from the beginning of the summer to the end of October. Most of the 
tasty Lycium were detected in the triangle of Székesfehérvár - Dunaújváros - Zalaegerszeg.

Hardwood cuttings were cut between 10 and 20 October 2009. Cuttings were set into seed trays with 66-144 cells. Porous, not coarse propagation media with efficient drainage property was applied. The soil mixture was the following: $2 / 3$ part of peat, $1 / 3$ part of perlite including $12-14$ months old Osmocote. The sprout cuttings were grown in a plastic tunnel under appropriate conditions. The clones were set between 10 and 20 of October 2009, and three plants per clone were planted between 20 and 27 of April 2010 into the clone repository.

Overall, 67 clones were planted in the clone repository, from which 4 were candidate varieties originating from various European nurseries. These clones were set into the clone repository for comparison.

Shrubs of the Lycium clones were examined in terms of various characteristics (shrub height, width and habitat). Clone 29 (as control) was compared with the examination results of the six 'best' clones. Characteristics (shrub height and diameter) of two year-old plants on 3 shrubs from each clones were measured by tape measure in October 2011 . Habits of the shrubs were characterised based on the shrub height and width ratio.

Flower set and crop load were estimated between 2011.04.30 and 2011.08.10 on the second years old plants. The blooming estimation categories: No flower $=0$; Only few flowers $=0,5$; Medium flower set $=1$; Good flower set $=$ 2 ; Very good flower set $=3$

Crop load categories: No berries $=0$; Only few berries $=0,5$; Light crop load $=1$; Medium yielding $=2 ;$ Good yielding $=3$.

The fruit size parameters were measured in different time in the ripening period according to ripening status of berries.

$3 \times 5$ (15) fruits were used from each genotypes as a sample for measuring of the typical characteristics of berries. The fruit weight of Lycium berries were measured with a digital balance. The length of the crops and his width a tenth accuracy I measured it with a digital calliper. The formal index of fruits was calculated from fruit length and the width.

The water-soluble sugar content (Brix\%), was measured with ATAGO PR 101-digital refractometer from smashed, and homogenised mash of 150 pieces frozen Lycium fruits.

HPLC analysis for nutrient content of the Lycium fruits:

Sample preparation. After thawing, fruit samples were placed in $1.5 \mathrm{ml}$ Eppendorf tubes and centrifuged (Hettich 23R) for $5 \mathrm{~min}$ at $15.000 \mathrm{rpm}$. One $\mathrm{ml}$ supernatant was then pipetted off. D-glucose, D-fructose and L-malic acid, analytical standards from Sigma-Aldrich Chemical Co. (3050 Spruce Street, St. Louis, MO 63103, USA), were used as HPLC standards. The standards were first dissolved in

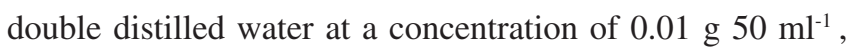
and a 1:50 dilution of these solutions was used for the HPLC analysis. Each measurement was repeated three times.

The HPLC equipment. The HPLC equipment (Waters Corporation, 34 Maple Street, Milford, MA 01757, USA) consisted of the following hardware: 2487 Dual Wavelength
Absorbance Detector (for the determination of organic acids), 2414 Refractive Index Detector (for the determination of sugars), 1525 Binary HPLC Pump, Colonna thermostat, 717 plus automatic injector. The equipment was controlled by the EmPower ${ }^{\mathrm{TM}} 2$ software programme.

Determination of sugars. The sugars were separated on a Sugar-Pak ${ }^{\mathrm{TM}}$ column placed in a thermostat at $90^{\circ} \mathrm{C}$. The mobile phase was a $0.0001 \mathrm{M}$ aqueous solution of $\mathrm{Ca}-$ EDTA [304695-78-1]. The flow rate was $0.5 \mathrm{ml} / \mathrm{min}$, leading to a pressure of $450 \pm 10 \mathrm{psi}$ on the column. Detection was continued for $30 \mathrm{~min}$. The injected sample quantity was 20 $\mathrm{ml}$. The retention time was $10.8 \mathrm{~min}$ for glucose.11.77 $\mathrm{min}$ for fructose.

The $\beta$-carotene: The definition of carotene content was based on the method drawn up by Konzerv Kutató. (KPKI method collection. 1990,2/4. method.)

The antioxidant capacity his definition (FRAP), Benzie and Stran happened with a modified method.

\section{Results and discussion}

Collected clones from the different areas of Hungary were planted in a trial orchard under uniform ecological (soil, moisture, precipitation, temperature) and growing conditions, and were compared objectively.

From among the 67 clones which can be found in the clone collection based on different viewpoints, selected the six best clones. Selected clones were compared to the control which is a cultivar of a foreign country delivery service.

Flowering and yielding were observed from spring to late autumn. From 67 collected genotypes 6 were selected as the best by the bush features, crop quantity, fruit size and it was not based on their flavour.

It was considered, that on the different clones when can be found most crops simultaneously, or which one bringing yielding towed. It was also considered the proportional fruit quantity to the bush size. It was also important in terms of the crop picking how soft their berry skin is, or, that how long they are storable without storage disorders. It was selected clones with no tasteless and without bitter aftertaste.

\section{Vegetative characteristics, bush sizes}

The measurement of vegetative parameters started in a two-year-old Lycium trial orchard in 2011, October. Height of bushes and the bush diameter were measured by tape measure. The ratio of bush height and diameter was calculated, giving information about the bush shape. By the statistical analysis of the data it was found significant differences between the height of bush and bush diameter of selected clones (Table 4.).

It was found that Hungarian selected genotypes (excepted clone No. 12) had less bush size parameters than the commercial cultivar (clone No. 29.) The shrub (plant) size has major effect on the spacing and growing conditions of the Lycium orchard. Of course the less plant size is not 
evaluated as a negative vegetative character, because by the compact growth of shrubs can be planted more intensive and more easily cultivated and harvested orchard. It is a question whether the moderate growth vigour interferes in the fertility.

Table 4. Bush size parameters and the calculated ratio of bush height and diameter in a two-year-old Lycium orchard, in 2011.

\begin{tabular}{|c|c|c|c|}
\hline $\begin{array}{c}\text { Clones' } \\
\text { number }\end{array}$ & $\begin{array}{c}\text { Height of the } \\
\text { bush }\end{array}$ & Bush diameter & $\begin{array}{c}\text { The ratio of } \\
\text { bush height and } \\
\text { diameter }\end{array}$ \\
\hline 55. & 73,33 & 143,67 & 0,51 \\
\hline 47. & 85,33 & 151,00 & 0,57 \\
\hline 21. & 86,67 & 154,00 & 0,56 \\
\hline 30. & 91,67 & 137,33 & 0,67 \\
\hline 67. & 112,67 & 168,67 & 0,67 \\
\hline 29. & 137,33 & 237,33 & 0,58 \\
\hline 12. & 141,00 & 200,00 & 0,71 \\
\hline
\end{tabular}

\section{Generative parameters, flower set and crop load}

Table 5. contains blooming and yield estimation data, which were collected in different times during the growing season. The clone No. 29. - used as the control in the field trial - showed very low blooming and yielding characteristic in the two-year-old plantation. Genotypes (clones) selected by us in Hungary showed more favourable values in both parameters.

Table 5. Flower set and crop load data based on estimation method in two-year-old Lycium orchard in 2011.

\begin{tabular}{|c|c|c|}
\hline $\begin{array}{l}\text { Clones' } \\
\text { number }\end{array}$ & Flower set & Crop load/Yielding \\
\hline 12. & 2 & 2 \\
\hline 21. & 2 & 3 \\
\hline 29. & 0,5 & 0,5 \\
\hline 30. & 2 & 2 \\
\hline 47. & 0,5 & 2 \\
\hline 55. & 1 & 2 \\
\hline 67. & 3 & 2 \\
\hline Comment & $\begin{array}{c}\text { No flower }=0 \\
\text { Only few flowers }=0,5 \\
\text { Medium flower set }=1 \\
\text { Good flower set }=2 \\
\text { Very good flower set }=3\end{array}$ & $\begin{array}{c}\text { No yield }=0 \\
\text { Only few berries }=0,5 \\
\text { Light crop load }=1 \\
\text { Medium yielding }=2 \\
\text { Good yielding }=3\end{array}$ \\
\hline
\end{tabular}

In the flower set the clone No. 67. was outstanding, but clones No. 12, 21 and 30 showed also good flower set. The clone No. 21. had the highest crop load and all the other clones selected by us resulted medium yielding capacity.

\section{The crop size parameters}

From among the fruit parameters, the size is the most considerable characteristic. Commonly measured fruit size parameters are the followings: the average fruit weight, longitude and width of fruits. In the average berry weight parameter data significant difference was found between genotypes. The clone No. 67 had the significantly smallest average berry weight (Table 6.). Clones No. 47. and 55. had the significantly largest berry weight. It was also significant difference between clones No. 67. 30. and 21., but they did not differ significantly from clones No. 12. and 29.

Table 6. The average berry size parameter in two-year-old Lycium orchard in 2011.

\begin{tabular}{|c|c|c|c|}
\hline $\begin{array}{c}\text { Clones' } \\
\text { number }\end{array}$ & $\begin{array}{c}\text { Average berry } \\
\text { weight }(\mathbf{g})\end{array}$ & $\begin{array}{c}\text { Homogeneous } \\
\text { group }\end{array}$ & $\begin{array}{c}\text { Compared to } \\
\text { the control } \\
\text { cultivar (\%) }\end{array}$ \\
\hline $\mathbf{6 7}$ & 0.28 & $\mathrm{a}$ & 45.66 \\
\hline $\mathbf{3 0}$ & 0.49 & $\mathrm{~b}$ & 80.26 \\
\hline $\mathbf{2 1}$ & 0.50 & $\mathrm{~b}$ & 81.45 \\
\hline $\mathbf{1 2}$ & 0.57 & $\mathrm{bc}$ & 93.06 \\
\hline $\mathbf{2 9} *$ & 0.61 & $\mathrm{bc}$ & 100.00 \\
\hline $\mathbf{4 7}$ & 0.64 & $\mathrm{c}$ & 103.69 \\
\hline $\mathbf{5 5}$ & 0.66 & $\mathrm{c}$ & 108.24 \\
\hline & \multicolumn{2}{|c|}{$\mathrm{SzD}_{5 \%}=0.13$} \\
\hline
\end{tabular}

* Clone No. 29. (a commercial cultivar) was applied as a control

The clones can be divided into three groups by the fruit size parameter (Figure 1.):

Small fruit size (avg. berry weight $<0,3 \mathrm{~g}$ ): clone No. 67.;

Medium fruit size $(0,3 \mathrm{~g}<$ avg. berry weight $<0,5 \mathrm{~g})$ : clones No. 30. and 21

Large fruit size $(0,5 \mathrm{~g}<\mathrm{avg}$. berry weight $<0,7)$ : clones No. 55, 47, 29 and 12.

The clone No. 55 significantly did not differ from the 29 clone applied as the control, but it had higher fruit weight by $8 \%$.

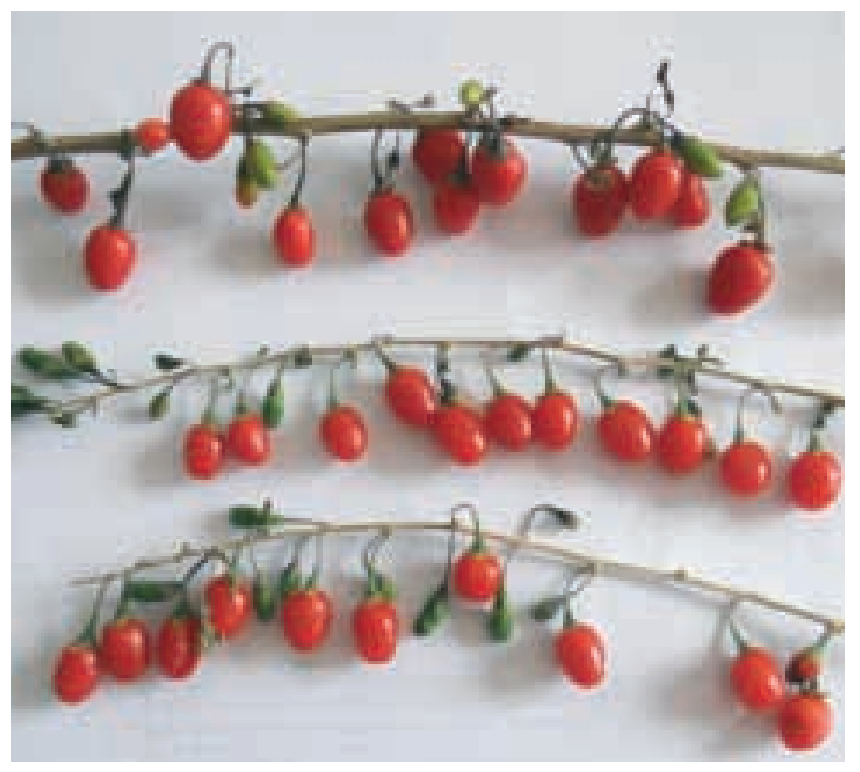

Figure 1. Comparison of Lycium fruit (berry) size, 2011. 
Table 7. The formal index of Lycium clone's fruit, 2011.

\begin{tabular}{|c|c|c|c|}
\hline $\begin{array}{c}\text { Clones' } \\
\text { number }\end{array}$ & $\begin{array}{c}\text { Formal index } \\
\text { of clone's fruit }\end{array}$ & $\begin{array}{c}\text { Homogeneous } \\
\text { group }\end{array}$ & $\begin{array}{c}\text { Compared to } \\
\text { the control } \\
\text { cultivar (\%) }\end{array}$ \\
\hline $\mathbf{1 2 .}$ & 1.80 & $\mathrm{a}$ & 98.50 \\
\hline $\mathbf{2 9 .} *$ & 1.82 & $\mathrm{a}$ & 100.00 \\
\hline $\mathbf{5 5 .}$ & 1.91 & $\mathrm{ab}$ & 104.83 \\
\hline $\mathbf{2 1 .}$ & 2.00 & $\mathrm{ab}$ & 109.58 \\
\hline $\mathbf{3 0 .}$ & 2.20 & $\mathrm{bc}$ & 120.72 \\
\hline $\mathbf{6 7 .}$ & 2.25 & $\mathrm{bc}$ & 123.45 \\
\hline $\mathbf{4 7 .}$ & 2.83 & $\mathrm{c}$ & 155.05 \\
\hline SzD5\% $=0.93$ & \multicolumn{3}{|l}{} \\
\hline
\end{tabular}

* Clone No. 29. (a commercial cultivar) was applied as a control

From the longitudinal and latitudinal data of fruits the formal index data of the crops was calculated.

This numerical value is the quotient of the longitude of the fruits and his width. The berry shape is more longish the value formal index is higher (Table 7.).

- Longish a little bit $(1.8>$ formal index $>2)$ : clones No. 12. 29 and 55;

- Medium longish ( $2>$ formal index > 2.5) clones No. 21. 30 and67

- $\quad$ Very longish (2.5 > formal index) clone No. 47 .

It can be seen clearly that there are clones selected by us with more favourable fruit size and growing parameters than the control (clone No. 29) which is already grown in abroad.

For different consumptions (dried fruits, dried fruits for tea or muesli) where the fruit size is determining it is offered to use the large fruited genotypes (clones No. 47 and 55).

For processing (jam, fruit juice) where the fruit size is not important, but the nutrition and inner content values are determining those clones are offered to use which have small fruits with higher nutrition and inner content values.

\section{Inner contents values of the tested Wolfberry genotypes}

For the processing industry the crops nutrition components (sugar, acids, antioxidant effect compounds and alkaloids) are defining the aims of suitability.

Table 8. Water-soluble total sugar content (Brix\%) of Lycium genotipes in 2011

\begin{tabular}{|c|c|c|c|}
\hline $\begin{array}{c}\text { Clones' } \\
\text { number }\end{array}$ & $\begin{array}{c}\text { Total sugar } \\
\text { content } \\
\text { (Brix \%) }\end{array}$ & $\begin{array}{c}\text { Homogeneous } \\
\text { group }\end{array}$ & $\begin{array}{c}\text { Compared to } \\
\text { the control } \\
\text { cultivar (\%) }\end{array}$ \\
\hline $\mathbf{2 9 . *}$ & 12.37 & $\mathrm{a}$ & 100.00 \\
\hline $\mathbf{5 5 .}$ & 14.63 & $\mathrm{~b}$ & 118.33 \\
\hline $\mathbf{4 7 .}$ & 15.03 & $\mathrm{c}$ & 121.56 \\
\hline $\mathbf{1 2 .}$ & 15.43 & $\mathrm{~d}$ & 124.80 \\
\hline $\mathbf{6 7 .}$ & 15.53 & $\mathrm{~d}$ & 125.61 \\
\hline $\mathbf{3 0 .}$ & 16.07 & $\mathrm{e}$ & 129.92 \\
\hline $\mathbf{2 1 .}$ & 16.13 & $\mathrm{e}$ & 130.46 \\
\hline
\end{tabular}

* Clone No. 29. (a commercial cultivar) was applied as a control
The sample fruit harvesting period was free of bigger amount of precipitation, so it means the weather conditions did not have effect on the sugar content of berries. Significant differences appeared between the observed clones in the total sugar content (Table 9.). All the clones selected by us showed higher total sugar content than the control clone No. 29. The significant highest total sugar content gave clones No. 30 . and 21., which had higher total sugar content by $30 \%$ than the control No. 29. clone.

Table 9. Glucose - fructose ratio of Lycium genotypes in 2011.

\begin{tabular}{|c|c|}
\hline Clones' number & Glucose / fructose ratio \\
\hline 47 & 0,988 \\
\hline 67 & 1,017 \\
\hline 21 & 1,018 \\
\hline 55 & 1,025 \\
\hline 30 & 1,041 \\
\hline 12 & 1,042 \\
\hline $29 *$ & 1,063 \\
\hline
\end{tabular}

* Clone No. 29. (a commercial cultivar) was applied as a control

The quantity and proportion of different sugar content (glucose, fructose, sorbitol etc.) is considerable character inside the total sugar content quantities. Glucose (retentions time: 10,3) and fructose (retention time: 12,3) quantitive analysis was made by HPLC equipment. From quantity of glucose and fructose it was calculated glucose - fructose ratio of Lycium berries. With one exception in the case of all observed Wolfberry genotypes the glucose content was higher than fructose content. Clone No. 47 was the exception, where the fructose showed higher level than glucose (Table 9.). Our results harmonize partly with result of Huang et. al., (1998), the glucose was measured as outstanding sugar component of Lycium barbarum, but the fructose was not mentioned.

Table 10. The average carotene content $(\mathrm{mg} / \mathrm{kg})$ of Lycium berries, in 2011

\begin{tabular}{|c|c|c|c|}
\hline $\begin{array}{c}\text { Clones' } \\
\text { number }\end{array}$ & $\begin{array}{c}\text { Carotene con- } \\
\text { tent (mg/kg) }\end{array}$ & $\begin{array}{c}\text { Homogeneous } \\
\text { group }\end{array}$ & $\begin{array}{c}\text { Compared to } \\
\text { the control } \\
\text { cultivar (\%) }\end{array}$ \\
\hline $\mathbf{6 7 .}$ & 181.75 & $\mathrm{a}$ & 78.81 \\
\hline $\mathbf{5 5 .}$ & 198.12 & $\mathrm{ab}$ & 85.91 \\
\hline $\mathbf{1 2 .}$ & 221.05 & $\mathrm{~b}$ & 95.85 \\
\hline $\mathbf{3 0 .}$ & 223.30 & $\mathrm{~b}$ & 96.83 \\
\hline $\mathbf{2 9 .}$ & 230.61 & $\mathrm{~b}$ & 100.00 \\
\hline $\mathbf{4 7 .}$ & 271.36 & $\mathrm{c}$ & 117.67 \\
\hline $\mathbf{2 1 .}$ & 305.23 & $\mathrm{c}$ & 132.36 \\
\hline & \multicolumn{2}{|c}{$\mathrm{SzD}_{5 \%}=37.08$} \\
\hline
\end{tabular}

The carotene content of Wolfberry fruit pulp was determined by spectrophotometric analysis. It was experienced significant differences between the clones in the carotene content (Table 10.). The clone No. 67. was found as containing the significantly lowest carotene content. 
Clones No. 47. and 21. showed the significant highest carotene values in their fruits. The clone No. 29 (used as the control) finished in the middle of field. The results showed that carotene content difference between observed genotypes reached even $50 \%$ value.

This difference can influence the consumption aims of the selected clones. Instrumental colour measurement of fruit pulp is planned in the future for verification of spectrophotometric analysis results. Based on our results fruits of clones No. 47. and 21. can be suitable for the making of natural fruit colouring matter.

The carotene antioxidant dissolving in fat effect compound that is why the high carotene content fruits of observed clones can be used as of functional foods. In our trial the carotene content of Wolf berries was determined because the carotene compounds are proportional, with the capacity of an antioxidant.

The FRAP method (Ferric Reducing Antioxidant Power) the water-soluble antioxidant is suitable for the definition of antioxidant capacity. The measured results showed significant differences between the observed Lycium genotypes. All the clones selected by us in Hungary showed higher FRAP value than the No. 29. clone used as the control (Table 11.).

Examined Lycium clones can be divided to four groups by the FRAP value their fruit pulp.

- Clones with the same FRAP value $(2,5-2,6 \mathrm{mM} / \mathrm{l})$ as No. 29. clone (control): clone No. 12.;

- Clones with slightly higher FRAP value (2,6-3 mM/l) than clone No. 29: clone No. 21.;

- Clones with significantly higher FRAP value (3-3,6 $\mathrm{mM} / \mathrm{l}$ ) than the control No. 29. clone: clones No. 30, 47. and 67.;

- Clones with outstanding FRAP value (3,6 mM/l and higher) compared to the control No. 29 clone: clone No. 55.

Table 11. Lycium clones' average FRAP values (mM/1), 2011

\begin{tabular}{|c|c|c|c|}
\hline $\begin{array}{c}\text { Clones' } \\
\text { number }\end{array}$ & $\begin{array}{c}\text { FRAP value } \\
(\mathbf{m M} / \mathbf{l})\end{array}$ & $\begin{array}{c}\text { Homogeneous } \\
\text { group }\end{array}$ & $\begin{array}{c}\text { Compared to } \\
\text { the control } \\
\text { cultivar (\%) }\end{array}$ \\
\hline $\mathbf{2 9 .}$ & 2.51 & $\mathrm{a}$ & 100.00 \\
\hline $\mathbf{1 2 .}$ & 2.53 & $\mathrm{a}$ & 101.05 \\
\hline $\mathbf{2 1 .}$ & 2.87 & $\mathrm{~b}$ & 114.59 \\
\hline $\mathbf{3 0 .}$ & 3.27 & $\mathrm{c}$ & 130.47 \\
\hline $\mathbf{4 7 .}$ & 3.40 & $\mathrm{c}$ & 135.58 \\
\hline $\mathbf{6 7 .}$ & 3.52 & $\mathrm{c}$ & 140.62 \\
\hline $\mathbf{5 5 .}$ & 4.08 & $\mathrm{~d}$ & 162.97 \\
\hline \multicolumn{4}{|c|}{$\mathrm{SzD}_{5 \%}=0.28$} \\
\hline
\end{tabular}

Similarly to the sand thorn and briar rose (Kovács et al., 2010) from which fruit juices, pulps, syrups are prepared for tumorous and cancerous patients, Lycium it would be possible to use for this aim especially fruits of selected clones No. 67 and 55 .

By the literature it is well known, that fruits with high colour matter content (sour cherry, small-berry fruits) usually have high water-soluble antioxidant capacity. The water soluble antioxidant capacity of measured Lycium clones is well commensurable to the water soluble antioxidant capacity of Hungarian sour cherry cultivars (Érdi bötermő - FRAP 2,45-2,75 mM/1 -, Kántorjánosi - FRAP 2,55-4,05 mM/l, IV-3/48 -4,47-7,50 mM/l; Ficzek, 2012; Ficzek et. al., 2009; Ficzek et al., 2010).

It was interesting that those clones which had higher FRAP values (clone No. 67 and 55) the content of the carotene was lower. Clones (No. 29, 21. and 12.) with higher carotene content had lower water-soluble antioxidant values (Figure 2.). To check this correlation, FRAP and TEAC analysis are planned in the future.

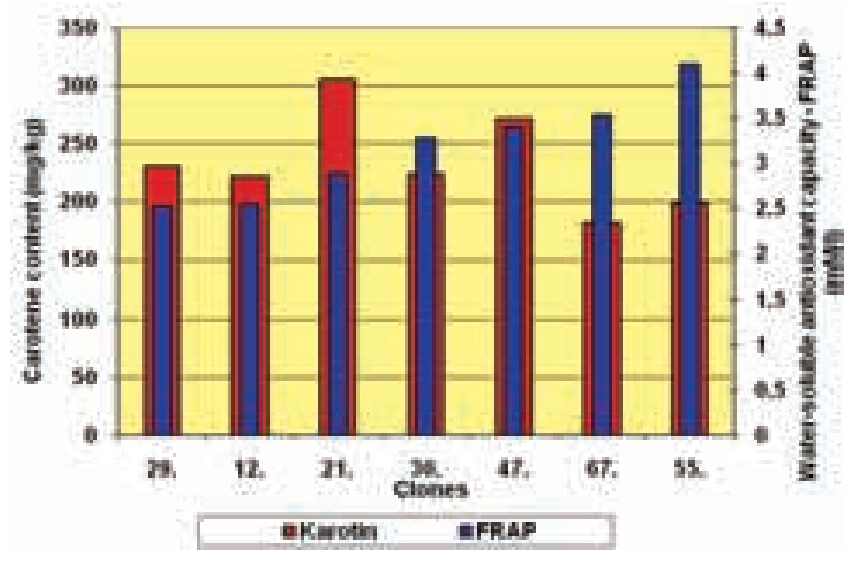

Figure 2. Carotene content and water-soluble antioxidant capacity (FRAP) of Lycium berries, in 2011.

Presented results justify that domestic Lycium population has favourable bush and fruit characteristics from the fruit growing aspect. Data above was based one-year laboratory measurements, so it is necessary repeat them in different years under different ecological and weather conditions in field trials. Examinations in the future should be included determinations of alkaloids (atropine and solanine), acids with the HPLC analytic method.

\section{References}

Bartha D. (1997): Fa- és cserjehatározó. Mezőgazda Kiadó. Budapest. 36: 112, 182, 238, 282 p.

Bartha D. (1999): Magyarország Fa és Cserjefajai. Mezőgazda Kiadó. Budapest. 138 p.

Ficzek G., Bujdosó G., Tóth M., Stégerné-Máté M., Nótin B., Kállay E., Szügyi S. (2009): Changes in the Antioxidant Components in Hungarian Bred Sour Cherry Cultivars during the Ripening Peroid. In: B.Patil, O. van Kooten, M-J. Amiot-Carlin. Acta Horticulturae 1040, Proceedings of the Third International Symposium on Human Health Effects of Fruit and Vegatables, Avignon, France, 84-85 p.

Ficzek G., Stégerné-Máté M., Nótin B., Kállay E., Szügyi S., Bujdosó G. and Tóth M. (2010): Inner content and processing industrial characteristics of new Hongarian bred sour cherry cultivar candidate. Review of Faculti of Engineering. Analecta Technica Szegediensia. Innovatív Nyomdaipari Kft., Szeged. 68-73. p. 
Ficzek G. (2012): A hazai alma és meggyfajták egészségvédő és felhasználhatósági értékei gyümölcsanalízis alapján. Doktori értekezés, Budapesti Corvinus Egyetem, Budapest.

Halmágyi L. (1991): Erdei és díszfák, cserjék. [In: Halmágyi L. \& Keresztesi B. (szerk.): A Méhlegelö.] Akadémia Kiadó, Budapest. 176 p.

Huang, L., Lin, Y., Tian, G. (1998): Isolation, purification and physicochemical properties of immunoactive glycoconjugates from fruit of Lycium barbarum L. Yaoxue Xuebao 33: 512-516 p.

Kovács, S., Udvardy, L. and Tóth, M. (2010): Breeding Rosa taxa native to the Carpathian Basin for fruit purposes - fruit quality. Acta Agronomica Hungarica, 58 (3): 273-281. p.

Krüssmann, G. (1977): Lycium In: Manual of Cultivated Broad Leaved Trees $\S$ Shrubs, Volume II, E-PRO, Timber Press, Oregon. 259-261 p.

Li, Z., Peng, G. \& Zhang, S. (1998): Separation and determination of carotenoids in Fructus lycii by isocratic non-aqueous reversedphase liquid chromatography. Chinese Journal of Chromatography, 16: 341-343 p.

Pap E. (2010): Szuperélelmiszer az Ördögcérna. Kertészet és Szőlészet, 21: 20 p.

Paul M. Gross (2006):Wofberry Nature's bounty of nutrition and health, Tables Ciqual (AFFSA)

Peng, G. H., Li, Z. \& Zhang, S. H. (1998): Separation and identification of carotenoids in Fructus lycii by thin-layer chromatography. Acta Nutrimenta Sinica, 20: 76-78 p.
Salamon P. (2002): Az Ördögcérna, mint vírusforrás. Kertészet és Szőlészet. 27: 15-16 p.

Schmidt G. \& Tóth I. (2006): A díszfák és díszcserjék ismerete [In: Schmidt G. és Tóth I., (szerk.): Kertészeti Dendrológia.] Mezőgazda Kiadó, Budapest, 275 p.

Schmidt G. (1996): A legfontosabb díszfák, díszcserjék szaporítása, nevelése és növényvédelme. [In: Schmidt G. \& Tóth I. (szerk.): Díszfaiskola.] Mezőgazda Kiadó, Budapest, 567 p.

USDA (2010): U.S. Department of agriculture, agricultural research service oxygen radical absorbance capacity (ORAC) of selected foods, release 2. Nutrient Data Laboratory

Vancsura R. (1992): A fás növények fejlődéstani és rendszertani vonatkozásai. [In: Gencsi L. \& Vancsura R., (szerk.): Dendrológia. Erdészeti növénytan II.] Mezőgazda Kiadó, Budapest, 689-700 p.

Weller, P. \& Breithaupt, E. (2003): Identification and quantification of zeaxanthin esters in plants using liquid chromatography-mass spectrometry. Journal of Agricultural and Food Chemistry, 51: 7044-7049 p.

Yong P., Chen M., YawelI L., Kelvin SZe-Yin L., Zhi-Hong J. \& Zhongzhen Z. (2005): Quantification of Zeaxanthin Dipalmitate and Total Carotenoids in Lycium Fruits (Fructus Lycii). Plant Foods for Human Nutrition 60: 161-164 p.

Young, G., Roland, L., Schreuder, M. (2006): Ningxia Wolfberry: the Ultimate Superfood. Esential Science Publishing. 